論 文

\title{
住宅居間の明るさ感一ダウンライトを設置した場合一
}

\author{
正会員 岩 井 彌 (松下電工株式会社) \\ 正会員 墨 貞 宏 (松下電工株式会社) \\ 正会員 齋 藤 良 徳 (松下電工株式会社) \\ 正会員 阪 口敏 彦(松下電工株式会社)
}

\section{Sensation of Brightness for a Living Room with Downlights}

Member Wataru Iwai (Matsushita Electric Works, Ltd), Member Yoshinori Saito

(Matsushita Electric Works, Ltd), Member Sadahiro Sumi (Matsushita Electric Works, Ltd) and Member Toshihiko Sakaguchi (Matsushita Electric Works, Ltd)

\begin{abstract}
The sensations of brightness perceived in a living room with downlights were investigated by psychological experiments with eighteen observers. Three positions and four types of downlight reflector were examined. The method of magnitude estimation was adopted to measure the sensation of brightness. In addition, the luminance of areas related to the sensation of brightness were measured with a CCD camera. The relationships between these luminances and the sensation of brightness are discussed.

The results showed that the sensations of brightness for a living room with downlights were strongly affected by "average luminance within the area of the front wall" and by "luminance in the corners of the room".
\end{abstract}

KEYWORDS : sensation of brightness, living room, downlight, luminance

\section{1. 緒言}

“明るさ”は照明を選ぶ上で重要な選定ポイントであり，“暗い” と感じる照明空間は好ましくないとされる，さらに対象を住宅の 居間の照明とした場合，オフィス空間とは異なり机上面での作業 が重要視されることは少ないので，ここで求められる“明るさ” とは部屋空間全体に対する印象としての“明るさ”，すなわち“明 るさ感”が求められていると推測できる。 さらに，環境保全の必 要性から，できるだけ少ないエネルギーで，この“明るさ感”を 実現することが今後ますます重要になってくると予測されること から，“明るさ感”を定量的に評価する方法の確立は重要であると 考之る。しかし，この“明るさ感”は，従来の照明設計のよりど ころとなっている机上面または床面の水平面照度だけで説明する ことができないことが知られている11.

\section{2. 明るさ感に影響を与える心理物理的要因}

部屋空間全体の明るさの印象である明るさ感に影響を与える要 因の明確化を試みた研究報告は過去に数多く存在する。 そして, それら研究から明らかにされた明るさ感と関連のある心理物理的 要因としては, 大きく分けて, “特定領域の平均輝度”と, “器具 の見かけの輝度”を挙げることができる.

\section{1 特定領域の平均輝度}

同じ配光の器具であれば，その器具により照明されている空間 本論文の一部は平成 9 年度照明学会全国大会で岩井弹が講演した。
を観察した時の視野全体の平均輝度が高輝度であればあるほど, より明るいと感じるのは自明のことであるが, 小林ら²゙，異なる 配光の器具間でもこの関係はほぼ成り立つことを明らかにしてい る. またLoe らの研究 ${ }^{3)}$ では, 上下方向視野角 40 度範囲内の平均輝 度が最も明るさ感を説明できるという結論を出しており, 明るさ 感と密接な関係のある観察領域の存在を示唆している。

さらに, 部屋空間の明るさ感に関連した部屋空間の gloom（日 本語では㓌気感という訳が最も近いと考える)に関する研究では, Shepherd らが, 過去の一連の研究から出てきた仮説を検証する 実験を行い, 部屋の隅の明るさの不足が部屋の gloom を生じる原 因と結論付けている4). 㓌気感と明るさ感の関係は非常に密接で あることから ${ }^{5}$, 部屋の隅の明るさ，すなわち輝度が足りないと明 るさ感の低下が生じることが予測できる.

以上のことをまとめると, 視野全体の領域や, 部屋の隅の領域 などの, 観察される部屋のある特定領域の平均輝度が高いほど, 部屋空間の明るさ感は高くなると予測できる。

\section{2 器具の見かけの輝度}

Bernecker ら $\left.{ }^{6}\right)$ は, 器具の見かけの輝度 (観察者が器具を見たと きの，その視線方向に㧍ける輝度）が $1000 \sim 4100 \mathrm{~cd} / \mathrm{m}^{2}$ の範讲で は, その輝度が高いほど明るさ感が増加することを明らかにした。 また明石らフは, 器具の見かけの輝度が輝き感を与える輝度で発 光したときに, 明るさ感が増加することを明らかにしている.

以上より, 器具の発光面が適切な輝度で発光した時に部屋空間 の明るさ感が高くなると予測できる. 


\section{3. 目的}

しかし，これら各研究では，対象とする要因を絞り込み，その 要因が明るさ感に与える影響を調查するように実験が計画されて いるため，以上述べてきた種々の要因が混在している実際の部屋 空間に対する明るさ感を説明することはできない，また，以上述 べてきた研究が対象とする空間は，そのほとんどがオフィス空間 であり，住宅居間に適用できる研究報告はほとんどないのが現状 である。

そこで今回，住宅居間の明るさ感を定量的に評価することを最 終目的として, 既往研究で検討された “特定領域の平均輝度” と,

“器具の見かけの輝度”の心理物理的要因が, それらが混在して いる実際の住宅居間の明るさ感にどのように影響するのかを調べ た。今回報告する実験では, 現在多く用いられているシーリング ライトにダウンライトを加えた照明手法を対象とした。

\section{4. 実験}

\section{1 実験空間と評価対象器具}

図 1 は今回の実験で用いた居間空間の平面図である。上図は什 器等の配置を示し, 下眓は各照明器具の設置位置を示している。 実験は, 図 1 の平面図に示寸部屋空間のうちの左側の間口 $3.5 \mathrm{~m}$,
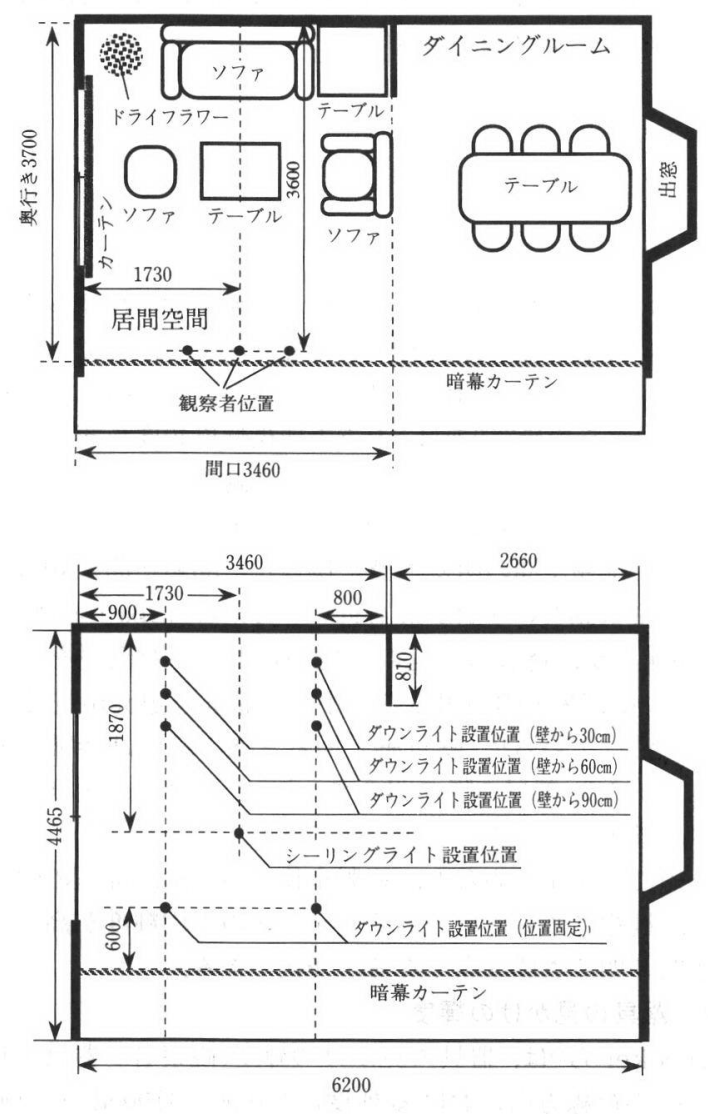

単位 $[\mathrm{mm}]$

\section{図 1 居間空間の平面図}

上図は什器等の配置を示し, 下図は各照明器具の設置位置を示している。左 側の部屋が今回実験に用いた居間空間である。

Fig. 1 Plan of the living room. Upper plan shows the location of furnitures and lower plan shows the location of luminaires. The left side room is the living room used in this experiments.
奥行き $3.7 \mathrm{~m}$ ，高さ $2.4 \mathrm{~m}$ の居間空間を用いて行った. 空間内には, 低彩度のカーテンやソファ, 机などを置き, シーリングライトを 天井中央に，ダウンライトを天井 4 隅に 4 灯設置した. 実験中, 右側のダイニングルームは消灯した。

評価対象となるダウンライトには，図 2 に示す一般的に良く使 われる 4 種類の開口直径 $125 \mathrm{~mm}$ の全般照明用ダウンライトを用い た (それぞれ, 器具 $\mathrm{A}, \mathrm{B}, \mathrm{C}, \mathrm{D}$ と呼ぶことにする)。これらダ ウンライトは反射板の形態が異なっており, 器具 A では鏡面仕上 げの反射板, 器具 $\mathrm{B}$ では白色塗装仕上げの反射板, 器具 $\mathrm{C}$ では鏡 面仕上げの反射板の開口部に白色塗装のバッフルを付加したもの を, そして器具 D では, 鏡面仕上げの反射板に黒塗装のバッフル を付加したものをそれぞれ反射板としている．正面壁側のダウン ライトは，壁からの距離が $30,60,90 \mathrm{~cm}$ の 3 段階の設置位置に設 置された。 すなわち, ダウンライト4種類, ダウンライトの設置位 置 3 段階の計 12 条件に対して, 今回実験を行った。また, シーリ ングライトの光源は $72 \mathrm{~W}$ で相関色温度 $3000 \mathrm{~K}$ の三波長型営光 ンプ, ダウンライトの光源はいずれも $60 \mathrm{~W} て ゙ 2800 \mathrm{~K}$ の白熱電球で ある。

\section{2 手順}

実験は明るさ感評価実験と, 前述の心理物理的要因に相当する 各輝度值の測定実験とからなる。そして，各実験条件に対する測 定実験から得られた各要因に相当する輝度值と, 明るさ感評価実 験から得られた明るさ感評価值との対応関係から，各心理物理的 要因が, 実際の照明空間の明るさ感にどの程度寄与するのかを調 査した.

明るさ感の評価はマグニチュード推定法を用いて行った。明る さ感の評価は部屋に入って部屋を見たその瞬間に行なわれるもの と考之, 観察者には部屋の入り口に相当する正面の壁から $3.6 \mathrm{~m}$ の 位置に立ってもらい評価をしてもらった。そして観察者には， シーリングライトのみ点灯させた基準照明空間全体に対して感じ る明るさ感を 100 とした時の, その基準照明空間に加えてダウンラ イト 4 灯を点灯させた評価照明空間に対して感じる明るさ感を数
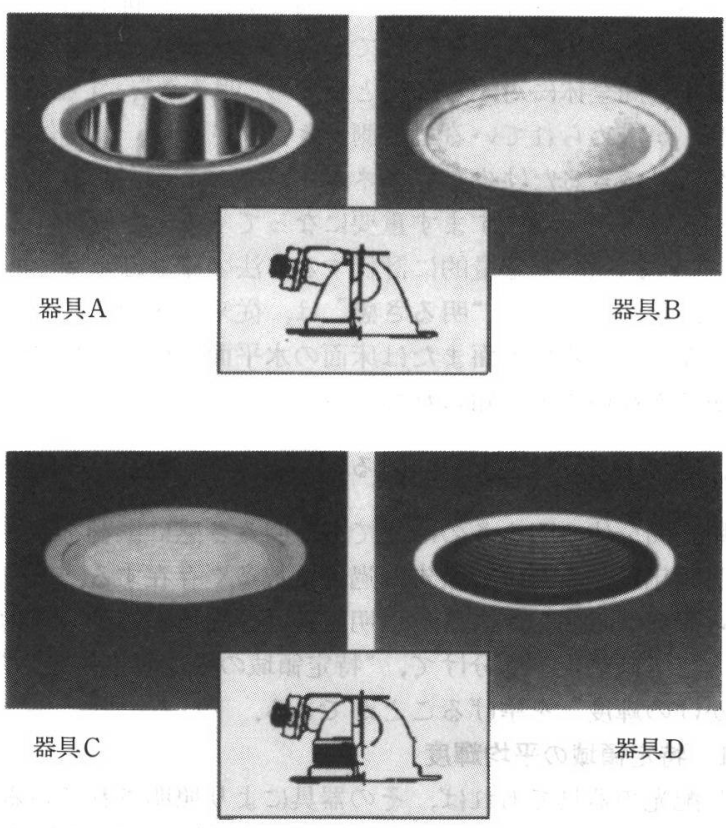

図 2 ダウンライトの外観図

Fig. 2 View of the downlights. 
值で評価することが要求された，例えば，シーリングライトのみ 点灯している基準空間に比べて, シーリングライトとダウンライ トの両方が点灯している評価空間全体に対して感じる明るさ感が 1.3 倍高いと感じたのであれば，観察者は 130 と評価した，基準照 明空間と評価照明空間は観察者が評価回答するまで，それぞれ 10 秒間交互に呈示された。観察者は18名, 評価の繰り返しは 1 回で ある。

各心理物理的要因に相当する輝度值の測定は, 観察者の観察位 置で，かつ平均的な視線高さ $(1.5 \mathrm{~m})$ から CCD カメラを用いて 撮影して得た $640 \times 480$ ドット（視角にして約 $105 \times 80$ 度）の画像 デー夕(図 3 〜図 5 ) を分析する方法で行った ${ }^{8}$. 要因 “ある特定 領域の平均輝度” に相当する輝度值は, 図 3 に示す画像全体（領 域 A）の平均輝度と, 観察者が評価時に良く注視すると思われる 図 4 の黒枠内に示寸正面壁に相当する領域 (領域 W) の平均輝度, そして, 図 5 に示す黒枠内の部屋の隅に相当する領域 (領域 C) の 平均輝度の 3 種類の領域の平均輝度值を測定した. さらに, 観察 位置から見えるダウンライトの反射板領域（領域 R）の平均輝度 を測定し, 要因 “器具の見かけの輝度”に相当する輝度值とした。

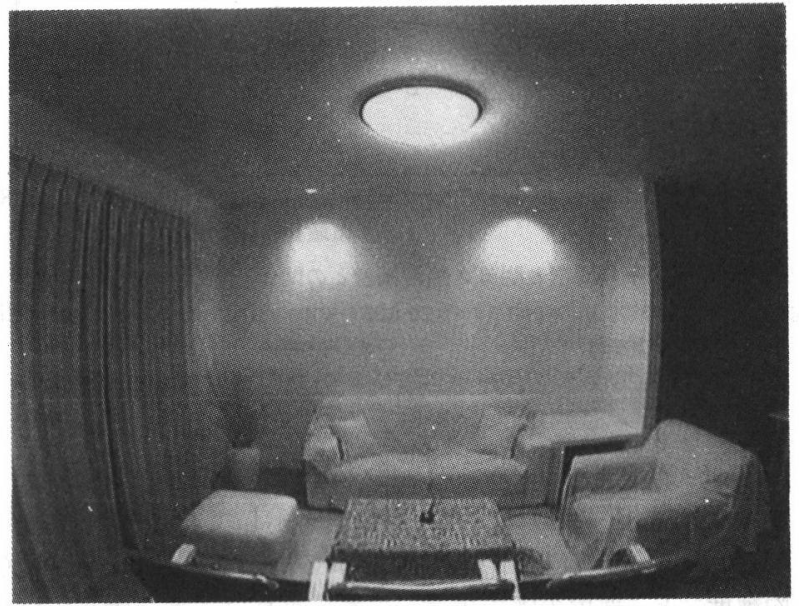

図 3 CCDにより撮影された画像

(領域 Aの平均輝度計算領域)

Fig. 3 Image of the living room taken by $\operatorname{CCD}$ (Area for calculating average luminance within area $A$ ).

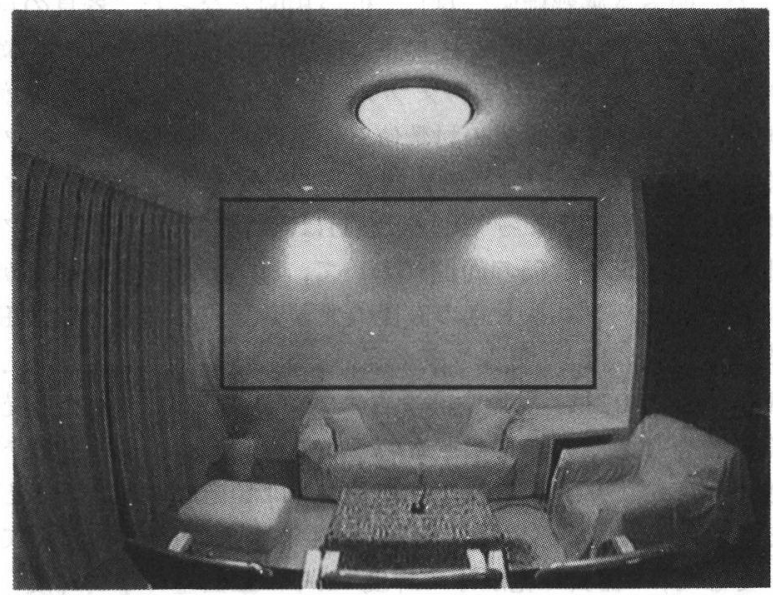

図 4 領域 W の計算領域

Fig. 4 Area for calculating average luminance within area W.

\section{3 結果}

図 6 は夕゙ウンライトの違い，並びにダウンライトの設置位置の 違いと, 実験によって得られた明るさ感評価值の全観察者に対す る平均値との関係を示している。横軸は器具の違い, 縦軸は明る さ感評価値であり, シンボルの違いは, 器具設置位置の違いを示 している. 図 6 は, 設置位置が壁に近くなるほど明るさ感が増加 することと, $60 \mathrm{~cm}$ と $90 \mathrm{~cm}$ の設置位置の時には器具 C が, $30 \mathrm{~cm}$ の時 には器具 A が最も高い明るさ感を与えるダウンライトであるこ とを示している。

また表 1 に，各実験条件に対して測定した 4 種類の領域の平均 輝度值をそれぞれ示す。

\section{5. 考察}

今回の実験を行った結果. 明るさ感評価值と相関の高かったの は, 図 7 と図 8 に示すように, 領域 $\mathrm{W}$ の平均輝度と領域 $\mathrm{C}$ の平均 輝度であり，それぞれ相関係数が，0.79と0.82であった。

これら二つの心理物理量の対数値を説明変数として, 明るさ感 評価値の対数值に対して重回帰分析を行ったところ，明るさ感評

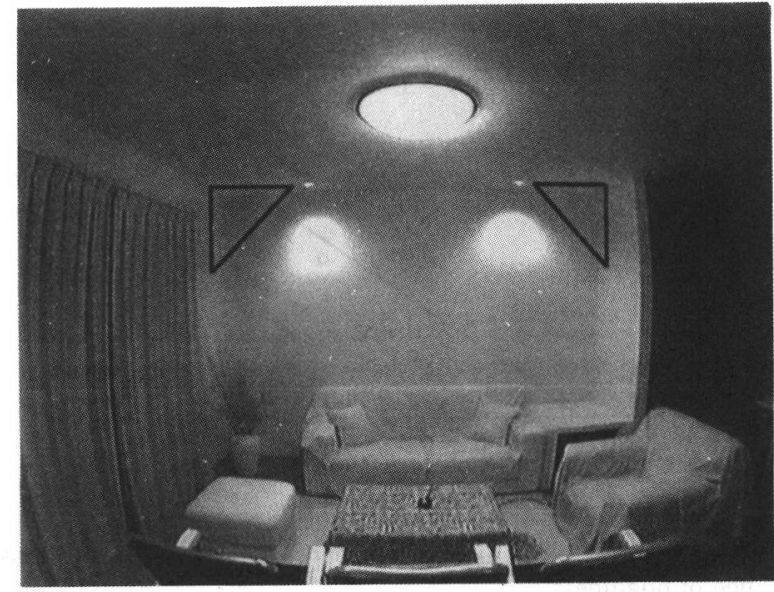

図 5 領域 C の計算領域

Fig. 5 Area for calculating average luminance within area C.

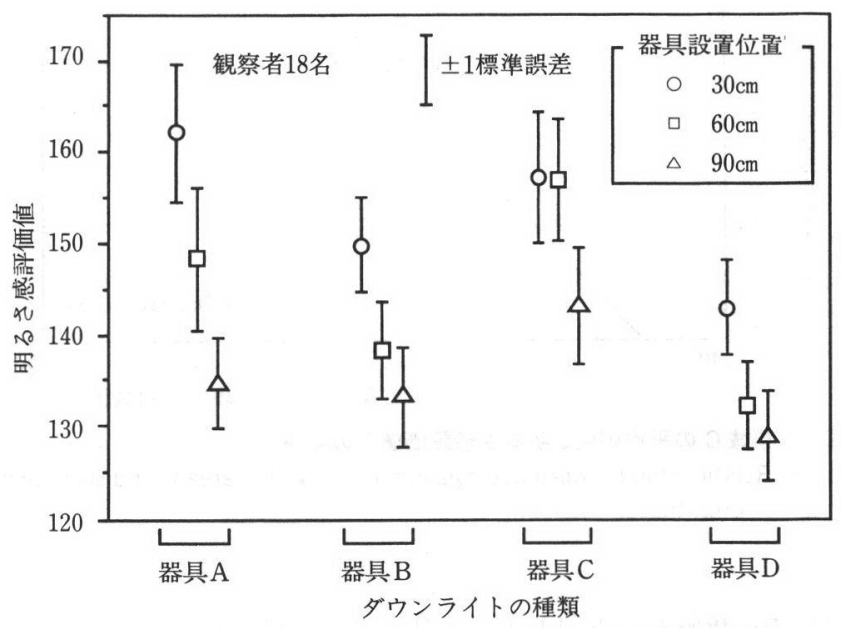

図 6 ダンライトと器具設置位置の違いによる明るさ感評価値の変化 縦棒は標準誤差

Fig. 6 Sensation of brightness in different downlights and locations. The bars show the standard error. 
表 1 各領域の平均輝度

Table 1 Average luminance of each calculating areas.

\begin{tabular}{|c|c|c|c|c|c|}
\hline \multirow{2}{*}{ 器 具 } & \multirow{2}{*}{ 設置位置（cm） } & \multicolumn{4}{|c|}{ 各領域の平均輝度 $\left(\mathrm{cd} / \mathrm{m}^{2}\right)$} \\
\hline & & 領域 A & 領域W & 領域C & 領域 R \\
\hline \multirow{3}{*}{ 器具A } & 30 & 53.9 & 46.9 & 31.2 & 520 \\
\hline & 60 & 53.7 & 43.6 & 30.6 & 680 \\
\hline & 90 & 52.2 & 39.5 & 29.0 & 740 \\
\hline \multirow{3}{*}{ 器具 B } & 30 & 50.1 & 40.3 & 30.0 & 4500 \\
\hline & 60 & 49.3 & 37.2 & 28.1 & 4300 \\
\hline & 90 & 49.2 & 36.1 & 27.3 & 4800 \\
\hline \multirow{3}{*}{ 器具 C } & 30 & 53.2 & 45.2 & 32.6 & 5600 \\
\hline & 60 & 52.4 & 41.7 & 31.3 & 5900 \\
\hline & 90 & 51.7 & 38.8 & 29.3 & 6000 \\
\hline \multirow{3}{*}{ 器具D } & 30 & 50.1 & 40.8 & 28.6 & 180 \\
\hline & 60 & 49.8 & 38.4 & 28.0 & 190 \\
\hline & 90 & 49.5 & 36.4 & 28.0 & 200 \\
\hline \multicolumn{2}{|c|}{ シーリングライトのみ } & 43.7 & 28.2 & 21.3 & \\
\hline
\end{tabular}

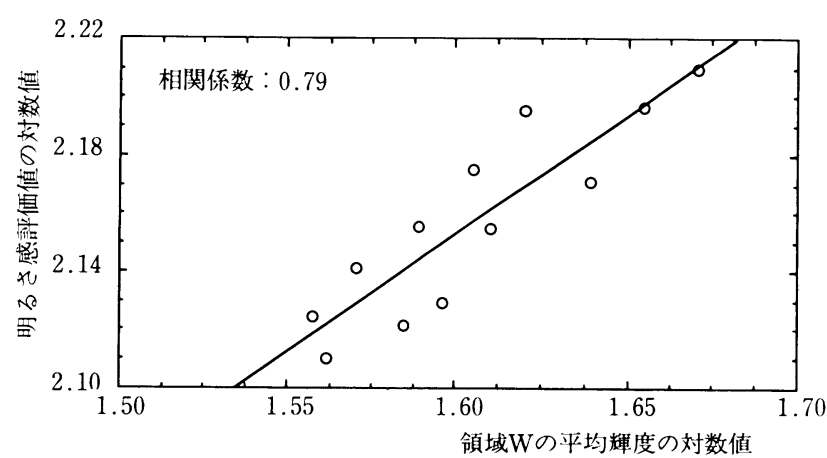

図7 領域 W の平均輝度と明るさ感評価値との関係

Fig. 7 Relationship between average luminance within area $W$ and sensation of brightness.

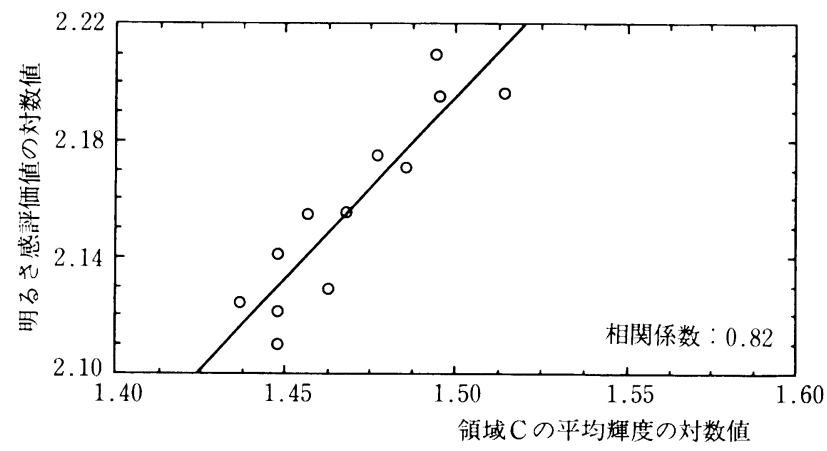

図 8 領域 C の平均輝度と明るさ感評価値との関係

Fig. 8 Relationship between average luminance within area $C$ and sensation of brightness.

価值の対数值を，下記(1)式で近似することができた.

$\log _{10} B r=0.36 \cdot \log _{10} L_{\mathrm{W}}+0.77 \cdot \log _{10} L_{\mathrm{C}}+0.46$

ただし, $\mathrm{Br}$ ：明るさ感評価值

$L_{\mathrm{W}}$ : 領域 $\mathrm{W} の$ 平均輝度 $\left[\mathrm{cd} / \mathrm{m}^{2}\right]$

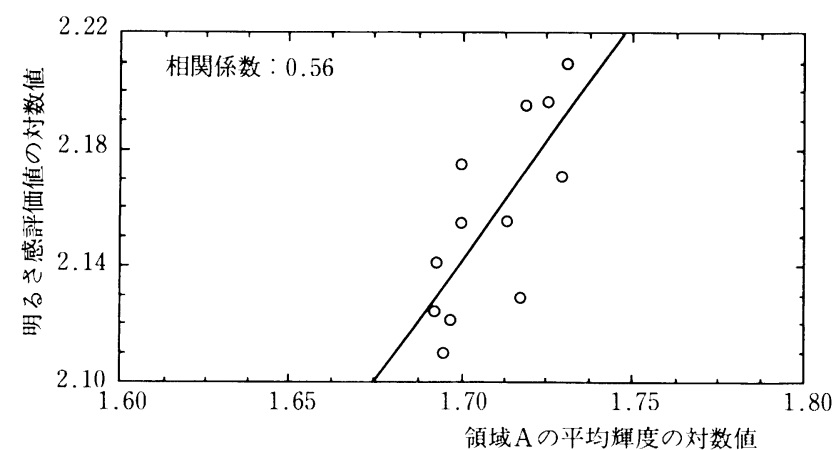

図9 領域 A の平均輝度と明るさ感評価値との関係

Fig. 9 Relationship between average luminance within area $A$ and sensation of brightness.

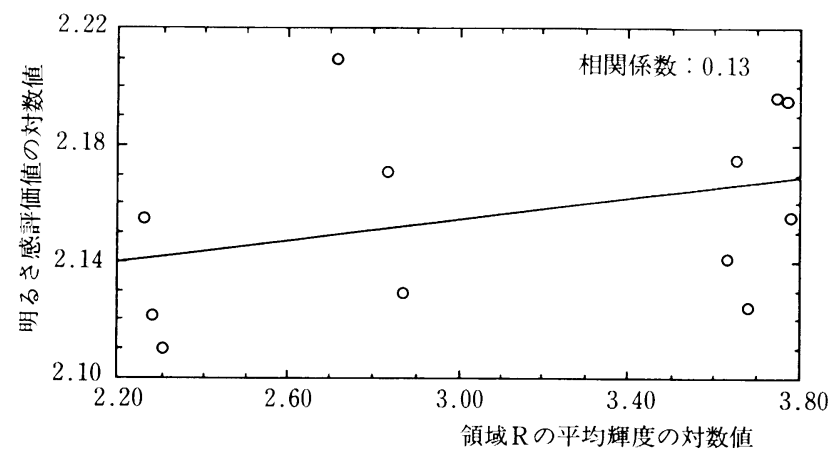

図10 領域 R の平均輝度と明るさ感評価値との関係

Fig.10 Relationship between average luminance within area $\mathrm{R}$ and sensation of brightness.

\section{$L_{\mathrm{C}}$ : 領域 $\mathrm{C}$ の平均輝度 $\left[\mathrm{cd} / \mathrm{m}^{2}\right]$}

この時の重相関係数は 0.92 と高い值を示しており,この結果は, ダウンライトを設置した住宅居間空間の明るさ感には, “正面壁の 平均輝度”と“部屋の隅の輝度”の奇与が高いことを示している.

一方, 領域 $\mathrm{A} の$ 平均輝度と領域 $\mathrm{R} の$ 平均輝度は, 図 9 と図10に 示すように領域 Cや領域 W の場合に比べて明るさ感評価值に対 し低い相関を示していた。この時の相関係数はそれぞれ，0.56と 0.13 であった.

ここで，明るさ感評価值に対して低い相関となった “器具の見 かけの晄度”に相当する領域 $\mathrm{R} の$ 平均輝度に対して，さらなる検 討を加之たい. 図11は，図 7 のグラフと同様, 領域 W の平均輝度 の対数值と明るさ感評価值の対数值との関係をプロットしたもの であるが，プロット点の直径の大きさが，領域 $\mathrm{R} の$ 平均輝度值の 大きさを表したものとなっている. 図11は, 領域 W の平均輝度の 対数值の低い1.55 1.65の範囲において, 領域 $\mathrm{W} の$ 平均輝度が ほぼ同等の場合，プロット点の直径の大きい，すなわち，領域 $\mathrm{R}$ の平均輝度が高いほど, 明るさ感が高いという傾向を示している. 領域 $\mathrm{W} の$ 平均輝度は, 視野中心を占めていることから, 眼の順応 に強く影響を与えたと推測できるので，この傾向は，部屋空間内 の輝きの存在により明るさ感を高める効果は順応輝度が低いほど 高いと言う明石らの研究7の結論と一致していると見ることがで きる．そして, “器具の見かけの輝度”が, “正面壁の平均輝度” や”部屋の隅の輝度”とは異なり，順忍輝度という他の要因の影 響を強く受けて明るさ感に奇与しているという性質を持っている 
がために，図10に示す検討では，明るさ感評価值に対する相関が 低いという結果になったと考えている。

以上述べてきたように，図11に示す検討結果は，“器具の見かけ の輝度”が明るさ感に影響を与えることを示唆するものである. しかし，これについては，デー夕数が少ないため，今後さらに詳 細な検討が必要である。

また, Loe らの研究3)で, 明るさ感に影響を与えると報告されて いた上下方向視野角 40 度範囲（以下，40度バンドと記す）内の平 均輝度を, 図 3 の油像デー夕から算出し, 明るさ感評価値との関 係を示したものが図12である. 相関係数は 0.65 と, 領域 W や領域 Cの場合に比べて, 低い值を示している.ここでの40度バンドの測 定範囲は，Loeらの検討で測定した範囲に比べ，横方向の測定範 囲が狭いので, Loe らの研究結果との完全な比較はできない.し かし, 今回の実験条件では, 四 3 の測定範用外の領域は主として シーリングライトにより照明されている領域であり，その平均輝 度の実験条件間の差は少ない。従って, 罒 3 から算出した 40 度バ ンドの平均值に対し検討した図12に示される傾向は，より横方向 に測定範囲の広いLoe らの40度バンドの範囲に対して測定した 結果と変わらぬ傾向を示すと見なせる.そして四12の結果は, Loe らの研究で報告された結論に反して，40度バンド内の平均輝度だ けでは，明るさ感を説明できないことを示した。

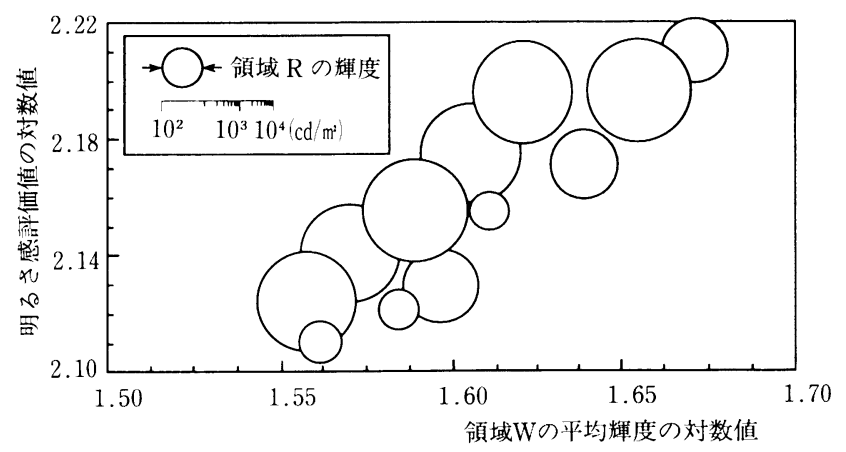

図11器具の見かけの輝度の影䈏

Fig.11 Influence of "luminance for the luminous part of a downlight".

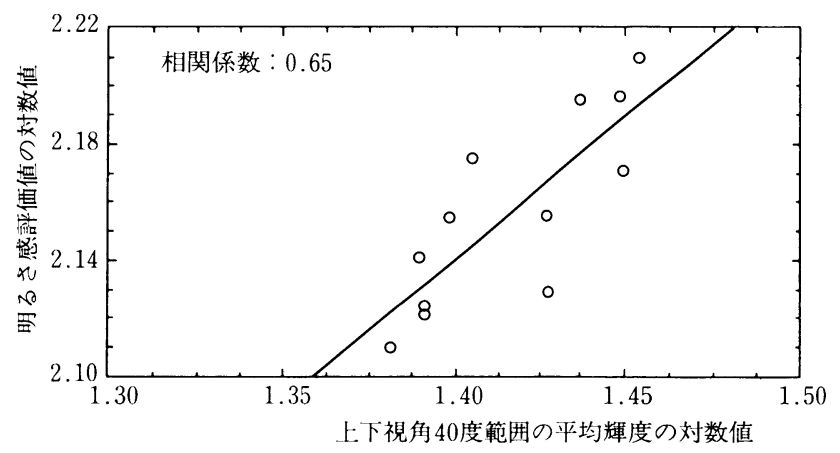

图12 40度バンド内平均輝度と明るさ感評価値との関係

Fig.12 Relationship between average luminance within horizontal $40^{\circ}$ band area and sensation of brightness.
以上述べてきた明るさ感評価值との相関が低いと判断された 40 度バンドに対する検討, ならびに図 9 に示す視角 $105 \times 80$ 度の領域 $\mathrm{A}$ の平均輝度に対する今回の検討結果は, 40 度バンド内の平均輝 度とオフィス空間での明るさ感との関係を検討して「40度バンド のように平均輝度算出領域を固定するのは困難である」と結論づ けた Nakamura ${ }^{9}$ の報告を支持するものである.

我々は照明された空間を観察する時, 素早く, かつ自然に, 空 間内の各対象物そのものの明るさと，その対象物を照明している

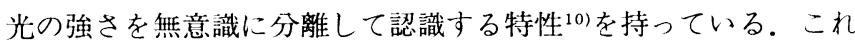
らの中で照明と関連の深い光の強さの認識は，古崎が照明印象と いう言葉を用い心理量として扱っている11). 今回の実験のように, 天井，壁，床や家具等の部屋の構成部の反射率は変わらず，照明 条件だけが変化する場合には，この照明印象の変化が生じている と言える。そして著者らは，部屋空間の明るさ感は，この照明印 象の影響を強く受け，その知覚量が大きいほど明るさ感は高くな るという仮説をたてている。なぜ本実験で, “正面壁”や“部屋の 隅”の領域の平均輝度が明るさ感評価值に対し高い寄与があった のかを推測すると，それら領域がそれぞれ，「どれだけの強い光が 壁に照射されているのか？」,「どれだけの光が部屋の隅までまわ っているのか？」という住宅居間における「照明印象」の認識に つながる領域であり, 部屋の明るさ感を認識するために必要な情 報を与える着目すべき領域であったためと見ている。 さらに著者 らは, 明るさ感の評価には, 前述の 40 度バンドのような固定され た領域ではなく, 今回の実験で “正面壁”や“部屋の隅”の領域 を用いたように，その空間の照明印象の認識につながる観察者が 評価時に注目する領域を採用するのが有効だと考えている.

今後は, 照明印象と明るさ感との関係を調査する実験を行い, 照明された部屋空間の明るさ感は照明印象の知覚が大きいほど高 くなるという著者らの仮説を検証していく予定である。そして， 照明により提供される空間の明るさ感を照明印象にもとづき検討 していきたいと考えている。

\section{6. 結言}

本研究では, 名ンライトの設置された住宅居間空間の明るさ 感を評価し, 明るさ感に影響を与えると推測される領域の輝度と の対応関係を検討した。 その結果，ダウンライトを設置した住宅 の居間空間の明るさ感には, “正面壁の平均輝度”と“部屋の隅の 輝度”の寄与が高いことが判明した。

今後は, 名ンライト以外の器具を用いた照明空間に関しても 検討をしていく予定である.

\section{参 考 文 献}

(1) 例えば, A.R.Bean: "Impression of Brightness of Object and Interiors”, Light. Res. Technol., 9-2, pp.103 106 (1977).

（2）小林, 木津, 中村, 乾：「室内光環境における明るさ感そ の 2 : 輝度分布と明るさ感の関係」, 日本建築学会大会学術 講演梗概集，pp.1157-1158（1993）.

(3) D. L. Loe, K. P. Mansfield and E. Rowlands: "Appearance of Lit Environment and Its Relevance in Lighting Design : Experiment Study", Light. Res. Technol., 26-3, pp.119-133 (1994).

(4) A. J. Shepherd, W. G. Julian and A. T. Purcell : "Gloom as a Psychophysical Phenomenon”, Light. Res. Technol., 
21-3, pp.89-97 (1989).

（5）宮本雅子：「天井照明が室内雾囲気に及ぼす影響に関する 実験的研究（第 4 報） 光源と床面色彩が室内雾囲気に及 ほす影響」, 家政学研究, 36-1, pp.35-42 (1989).

(6) C.A.Bernecker and J.M.Mier : "The Effect of Source Luminance on the Perception on Environment Brightness”, J. Illum. Engng. Soc., 15-1, pp.253-271 (1985).

（7）明石，明石，田辺，金谷：「照明器具の輝きによる明るさ 感増加効果 」, 照学全大, p.86 (1995).

（8）村上忠史, 阪口敏彦：「画像処理技術を応用した輝度分布 計測システム」, 照学全大, p.122 (1992).

(9) Y. Nakamura: "The Effect of Luminance Distribution on Subjective Assessments in an Office", Proc. Lux Europa '97, pp.102-115 (1997).

（10）池田光男, 金子文香：「照明認識視空間への初期視覚情報 の影響一明度と彩度の場合一」, 照学誌, 8-5, pp.319323 (1996).

（11）古崎愛子：「無彩色の心理的属性をめぐって」, 心理学評論, 22-2, pp.160-181 (1979).

(受付日1998年 4 月 1 日 / 採録日1998年10月 1 日)

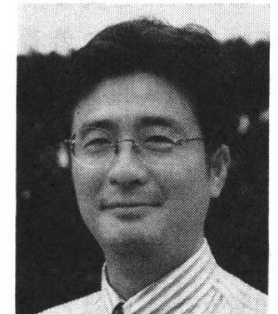

岩井膤 (正会員)

松下電工株式会社照明 $R \& D$ センター

昭和 42 年 1 月 10 日生まれ。平成 3 年 3 月千 葉大学大学院工学研究科画像工学専攻修士課 程修了, 同年 4 月松下電工怢)に入社, 現在照 明 R\&Dセンターで照明に関わる視覚心理と視認性の研究に従 事. 日本色彩学会, 日本視覚学会会員.

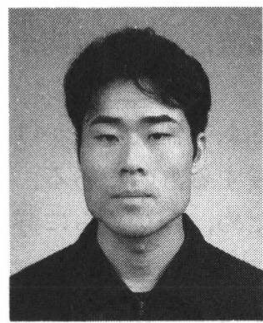

齋藤 良徳(正会員)

松下電工株式会社照明 $R \& D$ センター

昭和 44 年 5 月 14 日生まれ. 平成 6 年 3 月名 古屋大学大学院工学研究科建築学専攻博士課 程（前期）修了, 同年 4 月松下電工侏に入社, 現在照明 $R \& D$ センターで照明に関わる視覚心理と視認性の研究 に従事. 日本建築学会会員.

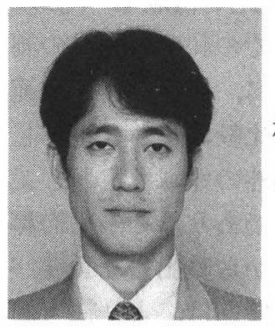

\section{すを墨暻宏 (正会員)}

松下電工株式会社東京インテリアライティン グセンター

昭和 44 年 12 月 19 日生まれ。平成 3 年 3 月豊 田工業高等専門学校建築学科卒業, 同年 4 月松下電工侏に入社, 現在東京 ILC（インテリアライティングセンター）で住宅照明に 関わる技術サポート，及びライティングプランナーに対する研修 活動に従事。

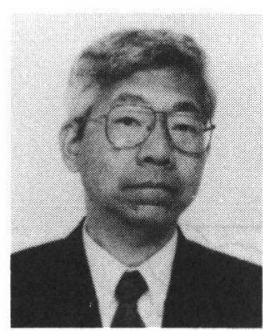

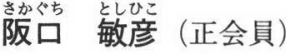

松下電工株式会社照明 $R \& D$ センター

昭和 26 年 10 月 10 日生まれ。昭和 52 年 3 月慶 應義塾大学大学院工学研究科電気工学専攻修 士課程修了, 同年 4 月松下電工侏に入社. 現 在照明 R\&D センターオプティックス開発部長. 日本色彩学会, 日 本視覚学会, 日本生理人類学会会員 